\title{
PRESENCE OF HEAVY METALS IN THE SOIL OF URBAN AREAS OF LUKAVAC AND KALESIJA AND MALIGNANT DISEASE PREVALENCE
}

Sanja Brekalo Lazarević, Edina Handžić, Abdel Đozić, Ivana Lazarević, Zahida Ademović, Edin Jusufović

(C) by Acta Medica Saliniana ISSN 0350-364X

Type of manuscript: Professional papers

\section{Title:}

PRESENCE OF HEAVY METALS IN THE SOIL OF URBAN AREAS OF LUKAVAC AND KALESIJA AND MALIGNANT DISEASE PREVALENCE

Running title: Heavy metals and malignant diseases

\section{Authors:}

Sanja Brekalo Lazarevic ${ }^{1}$,

Edina Handzic1, Abdel Djozic ${ }^{2}$

Ivana Lazarevic1, Zahida Ademovic ${ }^{2}$, Edin Jusufovic

\section{DOI: $10.5457 / 485$}

\section{Afiliations:}

${ }^{1}$ Faculty of Medicine, University of Tuzla, Bosnia and Herzegovina, ${ }^{2}$ Faculty of Technology, University of Tuzla, Bosnia and Herzegovina

\section{Received:}

11.01.2019.

\section{Corresponding author:}

Sanja Brekalo Lazarevic, PhD

Faculty of Medicine

University of Tuzla

75000 Tuzla

Bosnia and Herzegovina

Mob: +387 61729404

e-mail: sbrekalolazarevic@gmail.com

The development of industry, agriculture, transport and urbanization has resulted in excessive emissions of heavy metals into the environment, which due to their bioaccumulative properties express negative effects on the environment and living organisms as a whole. In this work the presence of heavy metals in the soil samples of the urban area of Lukavac and Kalesija municipality and their effect on the health of the population were studied. Soil samples were collected in October 2017 at five locations in the urban area of Lukavac municipality and two urban locations in Kalesija municipality. Concentrations of chromium ( $\mathrm{Cr}$ ) copper (Cu), cobalt (Co), nickel (Ni), cadmium (Cd), lead $(\mathrm{Pb})$, manganese $(\mathrm{Mn})$, iron $(\mathrm{Fe})$ and zinc $(\mathrm{Zn})$ in the soil samples were determined. The results indicated that in some locations the concentration of heavy metals exceeded the maximum permissible concentration (MPC). MPC value for chromium was exceeded at four locations in the urban area of Lukavac, whereas MPC value for nickel and cadmium was exceeded at all locations. In Kalesija, MPC value was exceeded for chromium and nickel at one location, while cadmium MPC was exceeded at both locations.

The negative impact of heavy metals on the health of the population is the cause of many malignant diseases. Statistical analysis of the number of patients with malignant diseases in the area of the Lukavac and Kalesija revealed significantly higher prevalence of malignant diseases of the breast and skin in the Lukavac $(p<0,05)$ in comparisson to Kalesija municipality.

Keywords: heavy metals, soil contamination, malignant diseases, urban area.

\section{INTRODUCTION}

Urbanization and industrialization in the area of Tuzla Canton (TC) and in particular municipality of Lukavac, have a significant impact on environmental pollution and deterioration of water, air and soil quality. Numerous industrial plants in the municipality of Lukavac discharge into environment large quantities of waste materials in solid, liquid and gaseous form. Among a large number of different types of pollutants released, heavy metals pose a great risk to the ecosystem, humans and animals (1). Heavy metals are substances that, when entering in the environment do not break down and have a long lasting negative impact on the ecosystem. Heavy metals in the different oxidation chemical state circulate in nature, through water and air reach the soil and plants and enter the food chain (2).

Heavy metals such as iron, zinc, chromium, copper, manganese, cobalt and molybdenum are essential and have an important role in the normal functioning of the living organism. Their deficiency, as well as their high concentration, may adversely affect the organism. Non- essential heavy metals such as arsenic, cadmium, lead, mercury, and nickel are not required for a normal functioning of living organism and can adversely affect human health (3).

Heavy metals may have toxic, carcinogenic, mutagenic, teratogenic, genotoxic, immunogenic or neurotoxic activity on humans. Arsenic, cadmium, lead, mercury, nickel and manganese have a long lasting negative impact on human health (4). Negative impact on human health due to increased presence of heavy metals in the environment can be manifested in different ways. According to the World Health Organization (WHO), lead poisoning in children can cause neurological damage, which may result in short term memory loss, learning disabilities and disturbance in movement coordination.

Acute heavy metal intoxications may damage central nervous function, the cardiovascular and gastrointestinal (GI) systems, lungs, kidneys, liver, endocrine glands, and bones. Chronic heavy metal exposure has been implicated in several degenerative diseases of these same systems and may increase the risk of 
some cancers (5-7). Environmental exposure to heavy metals is a well-known risk factor for cancers. Longterm low dose exposure of heavy metals may play a key role in tumorigenesis, and it may not be necessary to accumulate a high concentration of heavy metals in the human body for those metals to induce tumorigenesis (8). International Cancer Research Agency (IARC) classified cadmium in Group 1 carcinogen based on few studies of lung cancer in occupationally exposed populations (9). Cadmium has been associated with prostate cancer, but both positive and negative studies have been published. Early data indicated an association between cadmium exposure and kidney cancer (2). Nickel compounds are generally not carcinogenic in animals and, to a large extent, have not been considered potent human carcinogens, although recent studies have suggested an increase in cancer in nickel refinery areas where exposure to water-soluble nickel salts occurs (10). Some compounds of hexavalent chromium are also known for their human carcinogenic potential. The increased incidence of lung carcinoma is predominant, although tumors of other sides are also found (11).

Urban soil is an important part of the urban ecological environment and plays a vital role in the stability of the urban ecosystem. The quality of urban land has a major impact on urban landscape, quality of urban life and human health. The content of heavy metals in urban soil is generally higher than in the surrounding agricultural and forestry soil, because the urbanization process accelerates the exogenous introduction of heavy metals in the urban soil (12-14).

The aim of this study was to measure the concentration of heavy metals in the urban soils in the Lukavac and Kalesija municipalities and to assess their impact on cancer prevalence in the population of these municipalityes.

\section{MATERIALS AND METHODS}

\section{Chemicals}

All chemicals and reagents were of analytical grade. Heavy metals standard reagents were prepared from reagent grade chemicals (Perkin Elmer Pure - Atomic Spectroscopy Standard). All glassware were rinsed with detergent and distilled water three times prior to use.

\section{Soil sampling}

Soil sampling was conducted at five locations in Lukavac and two locations in Kalesija. Lukavac is selected as a municipality with developed chemical industry that greatly contributes to environmental pollution and Kalesija is selected as a control municipality with low polluting industry. Selected locations were green areas in the city center, near schools and kindergartens and are not close to industrial facilities. All samples were taken in October 2017. Concentration of chromium $(\mathrm{Cr})$, copper $(\mathrm{Cu})$, cobalt $(\mathrm{Co})$, nickel $(\mathrm{Ni})$, cadmium $(\mathrm{Cd})$, lead $(\mathrm{Pb})$, zinc $(\mathrm{Zn})$, manganese $(\mathrm{Mn})$ and iron (Fe) in soil samples was measured. Soil sampling was carried out according to the Instruction on procedures, practices and conditions for control of soil fertility (Official Gazette FBiH, No. 72/09). Soil samples were taken from 20-25 evenly spaced spots at each location at a depth of $0-10 \mathrm{~cm}$. For each location an average sample of approximately $2000 \mathrm{~g}$ was obtained by homogenization. Soil samples were dried in laboratory at room temperature to remove free moisture and sieved to a sieve hole diameter $0.2 \mathrm{~mm}$.

\section{Determination of heavy metals concentration}

Heavy metals concentration in soil samples was determined according to method BAS ISO 11047:2000 Soil quality - Determination of cadmium, chromium, cobalt, copper, lead, manganese, nickel and zinc in soil extract using aqua regia - Method of atomic absorption spectrometry (AAA).

Triplicate solid samples of approximately $0.5 \mathrm{~g}$ were dryed and digested in $12 \mathrm{~mL}$ freshly prepared aqua regia $(1 / 3 \mathrm{HNO}+2 / 3 \mathrm{HCl})$ for 16 hours at room temperature. After the destruction of samples, extracts were filtered in a $50 \mathrm{~mL}$ flask, which were then supplemented by deionized water. Total heavy metal concentrations $\mathrm{Cr}, \mathrm{Cu}, \mathrm{Co}, \mathrm{Ni}, \mathrm{Cd}, \mathrm{Pb}, \mathrm{Zn}, \mathrm{Mn}$, $\mathrm{Fe}$ ) were measured in soil extracts by Inductively Coupled Plasma-Optical Emission Spectrometer, ICPOES OPTIMA 2100 DV, Perkin-Elmer, with the standard of $100 \mathrm{mg} / \mathrm{L}$ for metals. The results were expressed in $\mathrm{mg} / \mathrm{kg}$ soil.

\section{Data on malignant diseases}

Data on malignancies were reported by the Public Health Institute of Tuzla Canton (TC).

\section{Statistical analysis}

The statistical analysis was performed with the Microsoft Office Excel 2007 Data Processing Program and the Online calculator for calculating the $\chi 2$ test (15). And during the analysis of acquired results $\chi 2$ test were applied.

\section{RESULTS}

Unlike most organic pollutants whose toxicity reduces over time, heavy metals can not be degraded or destroyed. Even more, by the bioaccumulation process, their concentration increases. Table 1. shows Maximum permissible concentration (MPC) of analysed heavy metals in agricultural land depending on soil texture. MPC for manganese and iron are not included in Official Gazette. 
Table 1. Descriptive statistic for patients with inferior myocardial infarction

\begin{tabular}{|lc|c|c|}
\hline \multirow{2}{*}{$\begin{array}{c}\text { Heavy metal, } \\
\text { total }(\mathbf{m g} / \mathbf{k g})\end{array}$} & MPC depending on soil texture & \\
\cline { 3 - 4 } & & sandy & dasty-clay \\
\hline Chromium & $(\mathrm{Cr})$ & 50 & 80 \\
\hline Copper & $(\mathrm{Cu})$ & 50 & 65 \\
\hline Cobalt $\quad(\mathrm{Co})$ & 30 & 45 \\
\hline Nickel & $(\mathrm{Ni})$ & 30 & 40 \\
\hline Cadmium & $(\mathrm{Cd})$ & 0.5 & 1.0 \\
\hline Lead & $(\mathrm{Pb})$ & 50 & 80 \\
\hline Zinc & $(\mathrm{Zn})$ & 100 & 150 \\
\hline
\end{tabular}

Tested soil sites are located in green urban areas of the municipalities. The results of heavy metals analysis in mg/ $\mathrm{kg}$ of soil samples at the tested locations in Lukavac municipality are shown in Table 2.

Table 2. Concentrations of heavy metals in soil ( $\mathrm{mg} / \mathrm{kg}$ soil) at five tested locations in Lukavac municipality. Values above MPC have been marked bold.

\begin{tabular}{|c|c|c|c|c|c|}
\hline $\begin{array}{l}\text { Heavy metal } \\
\text { (mg/kg soil) }\end{array}$ & $\begin{array}{c}\text { Park "Dom } \\
\text { kulture" Lukavac } \\
\text { (Location 1) }\end{array}$ & $\begin{array}{l}\text { Park “Dom } \\
\text { zdravlja” } \\
\text { Lukavac } \\
\text { (Location 2) }\end{array}$ & $\begin{array}{c}\text { Park “Macan } \\
\text { Marija” Lukavac } \\
\text { (Location 3) }\end{array}$ & $\begin{array}{l}\text { Park "Turski } \\
\text { Lukavac" } \\
\text { (Location 4) }\end{array}$ & $\begin{array}{c}\text { Kindergarten } \\
\text { Lukavac } \\
\text { (Location 5) }\end{array}$ \\
\hline & sandy & dasty-clay & clay & dasty-clay & sandy \\
\hline Chromium (Cr) & 80.06 & 83.29 & 76.93 & 80.68 & 42.32 \\
\hline Copper & 25.51 & 22.18 & 18.69 & 14.27 & 19.62 \\
\hline Cobalt & 28.97 & 38.40 & 27.95 & 35.41 & 29.30 \\
\hline Nickel & 121.54 & 137.56 & 88.44 & 110.23 & 66.67 \\
\hline Cadmium $(\mathrm{Cd})$ & 1.29 & 1.89 & 1.80 & 1.61 & 2.43 \\
\hline$(\mathrm{Pb})$ & 25.81 & 26.29 & 27.20 & 22.60 & 41.04 \\
\hline$(\mathrm{Zn})$ & 56.54 & 54.79 & 34.63 & 44.84 & 94.62 \\
\hline Manganese (Mn) & 10669 & 13350 & 8038 & 5309.6 & 11305 \\
\hline$(\mathrm{Fe})$ & 25401 & 24877 & 24173 & 24611 & 24668 \\
\hline
\end{tabular}

Heavy metals analysis of soil samples at two tested location in the Kalesija municipality are shown in Table 3.

Table 3. Concentrations of heavy metals in soil ( $\mathrm{mg} / \mathrm{kg}$ soil) at two tested locations in Kalesija municipality. Values above MPC have been marked bold.

\begin{tabular}{|l|c|c|}
\hline $\begin{array}{c}\text { Heavy metal } \\
(\mathrm{mg} / \mathrm{kg} \text { soil) }\end{array}$ & $\begin{array}{c}\text { Primary school Kalesija } \\
\text { (Location 1) }\end{array}$ & $\begin{array}{c}\text { Location near TC Kalesija } \\
\text { (Location 2) }\end{array}$ \\
\hline & dasty-clay & dasty-clay \\
\hline Chromium $(\mathrm{Cr})$ & 98.92 & 31.38 \\
\hline Copper $(\mathrm{Cu})$ & 24.86 & 11.65 \\
\hline Cobalt $(\mathrm{Co})$ & 30.12 & 27.13 \\
\hline Nickel $(\mathrm{Ni})$ & 146.03 & 27.67 \\
\hline Cadmium $(\mathrm{Cd})$ & 1.47 & 1.86 \\
\hline Lead $(\mathrm{Pb})$ & 33.02 & 39.20 \\
\hline Zinc $(\mathrm{Zn})$ & 54.78 & 73.99 \\
\hline Manganese $(\mathrm{Mn})$ & 9721 & 8805 \\
\hline Iron $(\mathrm{Fe})$ & 24704 & 24713 \\
\hline
\end{tabular}


Level of pollution (So) of heavy metals is calculated according to the following equation:

For the interpretation of the level of pollution the following criteria are used (17):

clean, unloaded soil $<25 \%$;

increased contamination 25 -50 \%;

high contamination 50 - 100\%;

contaminated $100-200 \%$;

polluted soil $>200 \%$ TLV.

According to the Level of pollution, at Location 1 in Lukavac the soil is contaminated, on Location 2 and 5 is high contaminated and on Locations 3 and 4 the soil is least polluted and according to the results it could be categorized as a soil with increased contamination.
At the Location 1 in Kalesija municipality, the soil is high contaminated, while at Location 2 the soil is less polluted and could be categorized as the soil with increased contamination. No location meets the Criteria for categorization as clean, unloaded soil.

According to the data from the Public Health Institute of Tuzla Canton (TC) 4715 malignant patients were registered in the period from 2010 to 2014 year, which is $1.06 \%$ of the total population in TC. Out of 4715 malignant patients, 2254 (47.80\%) were males and 2461 (52.19\%) females.

Regarding diagnosis, the largest number of patients in the tested period were diagnosed with lung cancer (651 patients or $0.146 \%$ ), followed by breast cancer (611 patients or $0.137 \%$ ) and the smallest number of patients were disagnosed with cervical carcinoma (356 patients or $0.080 \%$ ) (Figure 1 ).

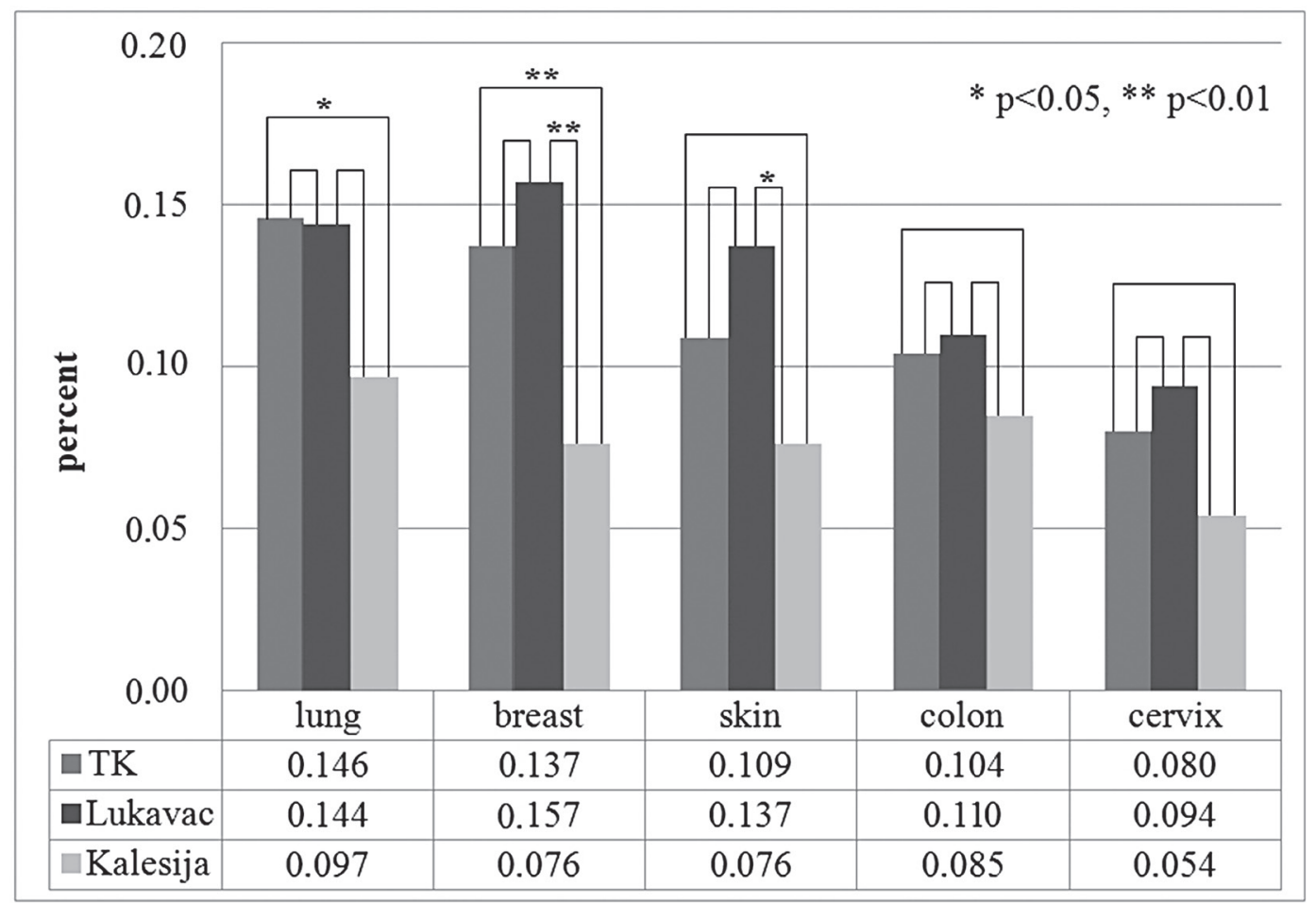

Figure 1. Number of patients with malignant diseases by diagnosis in Tuzla Canton, Lukavac and Kalesija municipalities in the period from year 2010 to 2014.

In the Lukavac municipality in the period from 2010 to 2014 , total 512 malignant patients, $(1.15 \%$ of the total population of Lukavac) were registered, out of which $238(46.48 \%)$ were males and $274(53.51 \%)$ females. Figure 1. shows the number of patients according to type of the malignant diseases in Lukavac for the tested period. The largest number of patients was diagnosed with breast cancer ( 70 patients or $0.157 \%$ ), followed by lung cancer (64 patients or $0.144 \%$ ) and skin cancer (61 patients or $0.137 \%$ ). The lowest number of patients was diagnosed with cervical cancer (42 patients or $0.094 \%$ )

Total 250 patients with malignant diseases were registered in Kalesija $(0.76 \%$ of total population of Kalesija), out of which 123 (49.20\%) were male and
127 (50.80\%) female. The largest number of patient was diagnosed with lung cancer and the lowest number was diagnosed with cervical cancer (Figure 1).

Figure 2. Shows statistical analysis of the number of patients with malignant diseases in Tuzla Canton (TC), Lukavac and Kalesija municipalities. The prevalence of malignant diseases of the lung and breast is significantly lower in the Kalesija municipality comparate to the TC.

The prevalence of malignant diseases of the breast and skin is significantly lower in the Kalesija municipality comparad to the Lukavac municipality where the concentration of heavy metals chromium, copper, cobalt, nickel, cadmium, manganese and iron is higher in the soil. 


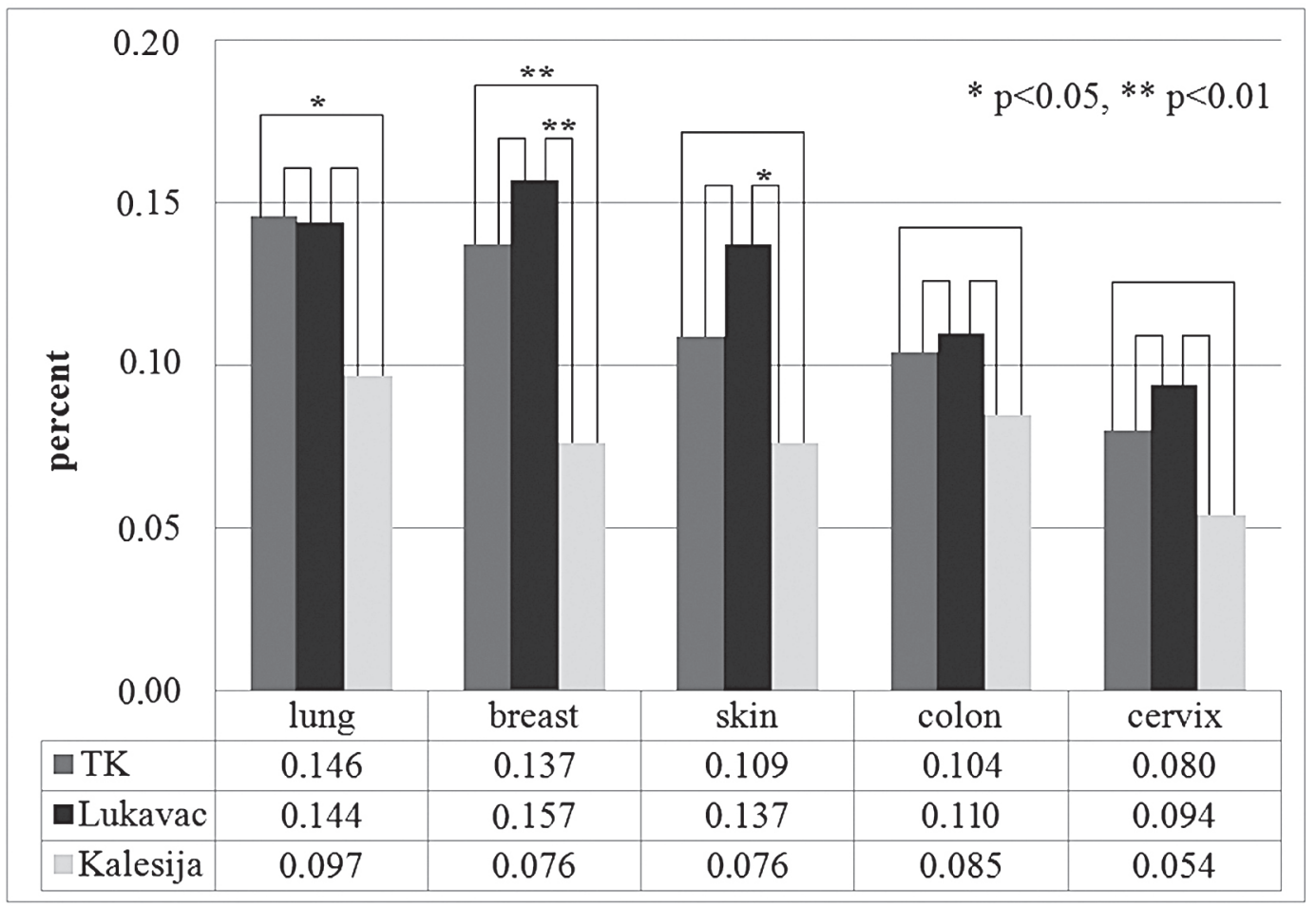

Figure 2. Prevalence of patients with malignant diseases by in Tuzla Canton (TC) and Lukavac and Kalesija municipalities in the period from year 2010 to 2014.

\section{DISCUSSION}

According to the results of heavy metal analysis of soil samples it can be concluded that the impact of industrial and urbanization sources, fossil fuels burning, and especially traffic, significantly contributes to the pollution of the soil with heavy metals in the urban area of Lukavac and Kalesija municipalities. Thise results are in accordance with previous studies. The study conducted in Podgorica in Montenegro showed a great impact of urbanization, especially traffic, on soil pollution with heavy metals (18). Another study in Brazil showed that $\mathrm{Cd}, \mathrm{Cu}, \mathrm{Pb}$ and $\mathrm{Zn}$ presence is soil is induced by human activity and the main source of diffuse pollution with heavy metals was the urban traffic (19). The study conducted in Russia showed that the growth of industrial production and vehicle emissions between 1989 and 2005 resulted in significant deposition of $\mathrm{Pb}, \mathrm{Zn}, \mathrm{Cu}$ and $\mathrm{Cd}$ in soil (20).

Particularly worrying is the fact that in all tested locations in Lukavac and Kalesija an increased concentration of one of the most dangerous heavy metals cadmium is registered. This is in line with similar study conducted in the coastal municipalities of Montenegro which showed an elevated Cd concentration in the soil of urban parks and playgrounds (21). Cd is one of major environmental risk factors which originate from contamination from anthropogenic, industrial and urban sources. Cadmium, Group 1 carcinogen, is primarily toxic to the liver and kidneys, digestive tract and can be incorporated into bone $(22,23)$. Cadmium also causes other negative effects on humans such as reproductive toxicity, teratogenicity, adverse effects on hematological, endocrine and immunological system (24). Also, at four locations in Lukavac and one location in Kalesija elevated concentrations of $\mathrm{Cr}$ were registered. $\mathrm{Cr}$ compounds cause skin and mucous membranes irritation and it is allergens to skin and lungs. According to IARC, $\mathrm{Cr}$ compounds belong to the Group 3 carcinogen (25), while the hexavalent $\mathrm{Cr}$ compounds are classified as Group 1 carcinogens. At all locations in Lukavac and at one location in Kalesija elevated $\mathrm{Ni}$ concentrations were measured. Ni bounds easily to plasma proteins (26).

From the results of this study it can be concluded that there is an increased concentration of heavy metals in the urban part of Lukavac municipality compared to the concentration of heavy metals in the urban part of Kalesija. Negative impact on human health due to increased presence of heavy metals in the environment can be manifested in different ways. Therefore, additional aim of this study was to evaluate the potential correlation of the presence of heavy metals in the soil of these two municipalities with the health disorder of the population, in particularly the emergence of malignant diseases.

Statistical analysis of the number of patients with malignantdiseasesintheKalesijamunicipalitycompared to the TC showed that the prevalence of malignant diseases of the lung and breast is significantly lower in the Kalesija municipality. Also, statistical analysis of the number of patients with malignant diseases in Lukavac and Kalesija municipalities found statistically higher prevalence of patients with malignant diseases of the breast $(\mathrm{p}<0.01)$ and skin $(\mathrm{p}<0.05)$ in the municipality of Lukavac where the presence of heavy metals $(\mathrm{Cr}, \mathrm{Cu}$, $\mathrm{Co}, \mathrm{Ni}, \mathrm{Cd}, \mathrm{Mn}$ and $\mathrm{Fe}$ ) is higher in the soil. There is a 
possible link between the presence of heavy metals in the soil of these two municipalities and the health disorder of the population.

\section{CONCLUSION}

The results of this study show that there is a significant degree of contamination in some soil samples, especially with chromium, nickel and cadmium in Lukavac municipality as well as cadmium in the municipality of Kalesija. These contaminations were most likely caused by anthropogenic activities, mainly from traffic. The maximum concentrations of these heavy metals were more than the allowable MPSs.

Statistical analysis of the number of patients with malignant diseases in Lukavac and Kalesija

\section{REFERENCES}

1. Ziemacki G, Viviano F, Merli F. Heavy Metals: Sources and Environmental Presence. Ann Ist Super Santita 1989;25:531536.

2. Jaerup L. Hazards of heavy metal contamination. Br Med Bull 2003;68:167-182.

3. Mertz W. The essential trace elements. Science $1981 ; 213: 1332-$ 1338

4. Mudipalli A. Metals (micro nutrients or toxicants) and global health. Indian J Med Res 2008;128:331-334.

5. Jaishankar M, Tseten T, Anbalagan N, Mathew BB, Beeregowda KN. Toxicity, mechanism and health effects of some heavy metals. Interdiscipl Toxicol 2014;7:60-72.

6. Martin S, Griswold W. Human health effects of heavy metals. Env Sci Technol Br Citizens 2009;15:1-6.

7. Lakherwal D. Adsorption of Heavy Metals: A Review. Int J Environ Res Develop. 2014;4(1):41-48.

8. Zhao Q, Wang Y, Cao Y, Chen A, Ren M, et al. (2013). Potential health risks of heavy metals in cultivated topsoil and grain, including correlations with human primary liver, lung and gastric cancer, in Anhui province, Eastern China. Sci Total Environm. 2013;470-471C:340-347.

9. IARC $1993 \mathrm{~b}$ Cadmium and cadmium compounds. IARC Monogr Eval Carcinog Risk Hum, 58:119-237.

10. Cempel M, Nikel G. Nickel: A Review of Its Sources and Environmental Toxicology. Polish J Environ Stud. 2006;15(3):375-38.

11. Becker N, Claude J, Frentzel-Beyme R. Cancer risk of arc welders exposed to fumes containing chromium and nickel. Scandin J Work, Environ Health.1985;11(2): 75-82.

12. Akan JC, Sodipo OA, Ochanya, AE, Askira YK. Heavy metals in sediments from River Ngada, Maiduguri Metropolis, Borno State, Nigeria. J Env Chem Ecotoxicol 2010;2:131-140.

13. Alloway BJ. Sources of Heavy Metals and Metalloids in Soils. In: Alloway B. (eds) Heavy Metals in Soils. Environmental Pollution, 2013:22.

14. Springer, DordrechtWei B, Yang L. A review of heavy metal contaminations in urban soils, urban road dusts and agricultural soils from China.Microchem J 2010;94:99-107. municipalities showed statistically higher prevalence of malignant diseases of the breast and skin in the municipality of Lukavac. There could be a possible link between the presence of heavy metals in the soil of these two municipalities and the health status of the population.

Soil in urban areas that were the subject of this study should be continuously monitored to provide insight into concentration of heavy metals. Based on the results of this study it is necessary to propose measures for the protection of the soil in order to protect population health. Further research over a longer period of time is required and more municipalities should be included to identify sources of soil contamination with heavy metals as well as assess their impact on population health.

15. Preacher, KJ. Interaktivni alat za izračun hi-kvadrat testa [software]. 2001. www.quantpsy.org, www.testovi.info/hikvadrat-test-kalkulator.html.

16. Pravilnik o utvrđivanju dozvoljenih količina štetnih i opasnih tvari u zemljištu i metode njihovog ispitivanja (Službene novine Federacije BiH", broj: 72/09).

17. Pravilnik o zaštiti poljoprivrednog zemljišta od onečišćenja (Narodne novine 152, 2008).

18. Mugoša B, Đurović D, Pirnat A, Bulat Z, Barjaktarović-Labović S. Procena rizika po zdravlje dece na osnovu sadržaja toksičnih metala $\mathrm{Pb}, \mathrm{Cd}, \mathrm{Cu}$ i $\mathrm{Zn}$ u gradskom zemljištu na teritoriji Podgorice, Crna Gora. Vojnosanitetski Pregled 2015;72:807812.

19. Manta DS, Angelone M, Bellanca A, Neri R, Sprovieri M. Heavy metals in urban soils: A case study from the city of Palermo (Sicily), Italy. Sci. Total Environ 2002:300:229-243.

20. Kosheleva NE, Nikiforova EM. Long-Term Dynamics of Urban Soil Pollution with Heavy Metals in Moscow. Appl Environm Soil Sci, vol. 2016

21. Mugoša B, Đurović D, Nedović-Vuković $M$, BarjaktarovićLabović S, Vrvić M. Assessment of Ecological Risk of Heavy Metal Contamination in Coastal Municipalities of Montenegro. Int J Environ Res Public Health 2016;13:393-408.

22. Agency for Toxic Substances and Disease Registry. Toxicological Profile for cadmium. ATSDR, 2012. https://www.atsdr.cdc.gov/ toxprofiles/tp5.pdf

23. Godt J, Scheidig F, Grosse-Siestrup C, Esche V, Brandenburg P Reich A, Groneberg DA. The toxicity of cadmium and resulting hazards for human healt. J Occup Med Toxicol 2006;1:22-28.

24. Bernard A. Cadmium \& its adverse effects on human health. Indian J Med Res 2018;128:557-64.

25. IARC monographs100C, Chromium (VI) compounds 147 167, Lyon, France. https://monographs.iarc.fr/wp-content/ uploads/2018/06/mono100C-9.pdf

26. Das KK, Das SN, Dhundasi SA. Nickel, its adverse health effects \& oxidative stress. Ind J Med Res 2008;128:412-425. 